\title{
The Governance of Fair Trade System: Evidence from Small Honey Producers in Rio Grande do Sul
}

\author{
Luciana Marques Vieira * \\ E-mail address: 1mvieira@unisinos.br \\ Universidade do Vale do Rio dos Sinos - Unisinos \\ São Leopoldo, RS, Brazil.
}

\section{Tatiana Maia}

E-mail address: tmaia@cpovo.net

Faculdades Integradas de Taquara - Faccat

Taquara, RS, Brazil.

\begin{abstract}
This paper discusses Fair Trade [FT] certification as a way to include small producers in global value chains, and identifies the main barriers for small honey producers from RS to meet these criteria. A new trading system such as FT has been providing access for food products coming from small farmers from developing countries. The method of this study integrates global value chain analysis and the methodology proposed by Paul (2005) to analyse FT as development projects. This study is three-fold: first to characterise the FT system; then to present the role of governance by third party certifiers such as FLO-CERT and finally to provide empirical evidence of the main difficulties that small producers have to comply with FT, such as export and organisation capacity. Our findings show that large retailers recently became big players in the FT system. The certification costs are high but can provide market access though there is a risk of overspecialisation.
\end{abstract}

Key words: small producers; global value chain; fair trade system; standards; international market.

Received 16 January 2008; received in revised form 10 June 2009.

Copyright (C) 2009 Brazilian Administration Review. All rights reserved, including rights for translation. Parts of this work may be quoted without prior knowledge on the condition that the source is identified.

* Corresponding author: Luciana Marques Vieira

PPG em Administração UNISINOS, Av. Unisinos, 950, São Leopoldo, RS, 93022-000, Brazil. 


\section{INTRODUCTION}

This paper is part of wider research on the role of certification on providing market access to small agri-food companies/producers. This paper, specifically, makes an exploratory assessment of the Fair Trade certification and its viability for small honey producers. In recent years, a new trading paradigm such as Fair Trade [FT] has transformed the traditional modus operandi of international food chains by providing an alternative market for food products coming from small farmers in developing countries (Lewin, Giovannucci, \& Varangis, 2004). While the FT channel has provided opportunities for small farmers, the initial certification costs can be prohibitively high and have limited the potential outreach of the fair trade alternative. To ensure that the small producers benefit from the FT system, there is need for a greater understanding of the adoption pattern as well as the socio-economic benefits to be gained from the involvement of farmers in FT.

The aim of this study is three-fold. The first is to characterise the FT market. The second is to present the role of third party certifiers such as FLO-CERT. Clear rules, inspection and trustworthy certification are key-points for FT assurance and responsible for organising and transferring technical and marketing knowledge from the consumer market to producers located in developing countries. Finally, we provide an empirical analysis of the main difficulties that small producers face in order to comply with FT, using evidence from honey producers in Rio Grande do Sul State.

The paper, besides this introductory section, is organised as follows: second section discusses the theoretical framework of the study; third section describes the method employed; fourth section presents the main findings of the research; finally, fifth section draws the final remarks and provides suggestions for future research.

\section{THEORETICAL FrameWORK}

\section{Fair Trade}

FT originated in 1960s, when NGOs and European and American consumer groups started selling products made by small producers victimized by poverty or by commercial isolation (World Fair Trade Organization [WFTO] - http:// www.wfto.org).

In the late 1980s, the first formal initiatives of collaboration appeared. Today FT counts on a large number of organizations spread all over the world. The most widespread FT concept was adopted in the annual International Federation Alternative Trade [IFAT] Conference that was held in 2001 in Arusha, Tanzania. It states that Fair Trade consists of a commercial partnership based on dialogue, transparency and respect that seeks the best equality. FT products were initially sold in churches and small charity shops, where the consumers and sellers had a trustworthy relationship. Today, FT products reach the market through the Alternative Trade Organizations [ATO's], which identify the products and import and commercialize them through a variety of channels such as church fairs, the internet and their own shops, among others (Jones, Comfort, \& Hillier, 2004). Nowadays, the commercialization also includes retail chains.

The Fair Trade [FT] movement has spread in the shadow of the tensions caused between the more industrialised and less industrialised countries with respect to market liberalisation, openness, protection and limited market access for agricultural products. Fair Trade is understood as a new way of looking at a production and market system in an attempt to overcome market imbalances, especially for small farmers. It also attempts to address issues of market access by creating specialist marketing channels and networks that operate parallel to the existing trading system. Nevertheless, in order for this to happen, the requirements for operating at the international trading level are often codified by 
standards which are also imposed upon producers. Thus, those engaged in Fair Trade have to follow basic principles, such as:

. direct purchasing from farmers

transparent and long-term trading relationships

. agreed minimum prices, and

. a focus on development and technical assistance through the payment of an agreed social premium.

Since Fair Trade makes use of the conventional trading system, it uses credence apparatus to closely mimic the market practices. In the evolution of FT in agri-food products, the quest for product certification as a differentiation tool works in opposition to the global undifferentiated homogeneous market.

Businesses such as the honey producer cooperative in Brazil that can capture these ideas and then communicate them to their consumers have been found to be more sustainable (Aguiar, 2006) and more successful in overcoming barriers and accessing different markets. To engage in either a mainstream or niche market strategy means positioning a business to supply a superior quality product either across the market or to a chosen market segment (Porter, 1985).

The FT market is still restricted to consumers that are sensitised by ethically-driven demand. Such businesses offer products that are perceived to be socially responsible (Harrison, Newholm, \& Shaw, 2005). Here the ethical dimension provides enough differentiation for consumers to choose between businesses and products. In this sense, credibility in the way a good is produced and traded provides an alternative to industrialised products with high in-built technology that sometimes threaten social relationships, the environment, animal welfare and human health (Harrison et al., 2005).

Low and Davenport (2006) recount how FT started as a alternative way of commercialisation but nowadays, when large retail chains are the main channels for these products, it can be characterised as an assimilation discourse. FT is not a lifestyle anymore, but a branding which competes against other leading brands.

The high income Northern consumer is reaching a point of saturation regarding product choice, especially if the product in question is of high value. Thus, there is a move in the market towards goods that provide an emotional connection. The case of FT honey from Brazil that can communicate naturalness, organic production and stories of the people who manage the bees will embody a sense of community that can lower the barriers to market access. Nevertheless, as regulatory frameworks become more entrenched as a means of further defending markets in more industrialised markets, producers will need to meet even more demanding requirements. Simply achieving product differentiation may not be enough. Eventually the consumer will move on and, therefore, product innovation should continue to identify new ways of fulfilling consumer demand.

\section{Global Value Chain}

The discussion will move on to understanding governance, in this case fair-trading governance, and how it has shaped the sector. The global food trade system has shown a growing concentration of buying power in retail channels through the proliferation of sourcing from overseas. This connectivity also depicts that common consumption and production patterns have spread to many different countries. The Global Value Chain $[\mathrm{GVC}]$ is a method of analysis focusing on governance structure and institutional framework within global production and the spread of sourcing and manufacturing throughout developing countries. Gereffi (1994) differentiates two types of chain configuration and governance structure: producer driven and buyer driven. The first means chains where large companies (usually transnationals) co-ordinate the whole supply chain and is characterized by capital and technology intensive industries such as automobiles and computers. Here, the main strategy is to 
attain economies of scale in manufacturing. Traditional examples are automobile companies such as Ford and General Motors. Conversely, buyer-driven chains focus on the domination of retail companies and brand-named merchandisers. These compete intensively against each other by continuing minor innovations to products and packaging, the maintenance of strict quality criteria and price. Traditional examples are UK supermarkets, Nike and Reebok (Dolan \& Humphrey, 2000; Gereffi, 1999; Kaplinsky, 2000). These companies are merchandisers that design or market the products that they sell. The key agent, the so called governor, delegates, manages and enforces the production process to ensure that its supply chain really complies. Gereffi (1994) also recognizes that both systems, the buyer and the producer-driven, may be contrasting, but not mutually exclusive. Large companies play the role of the governor, creating and monitoring their own standards. They can be manufacturers holding technological and production information (producer-driven) or retailers or branded companies concentrating on the possession and translation of market information.

Traditionally, the food industry has displayed the characteristics of the producer-driven chain, dominated by large processors such as Nestlé and Heinz. This pattern has been changing due to the concentration of retailing, hence challenging the position of large processors. The governor of the chain, i.e. the one responsible for setting the standards, should have sufficient size and capacity to monitor the standards, whilst the supplier should have the capacity to invest to meet the standards. However, Dolan and Humphrey (2000) showed that processors in developing countries have difficulties in meeting the requirements of UK supermarkets in respect of, for example, food safety, care for the environment and labour. Still, Vieira and Traill (2008), analysing the Brazilian beef chain through a global value chain approach, conclude that there is a gap between practices adopted for the export market and practices to supply markets in developing countries.

Raynolds, Murray and Wilkinson (2007) consider this typology useful to understand FT relationships, which move from market, where price is the main requirement, to tighter relationships, where trust and knowledge transfer may evolve. However, they also state that this system is cocoordinated not only by economic reasoning but also by the role of external agents and institutions.

Market governance suggests a traditional view of price as the main requirement. In modular governance though, codification of information leads to production chain segmentation, with frequent transactions and relative supplier independence. Relational governance involves solidarity and cooperation with more balanced power between parties. Captive governance indicates a more clear coordination between processors and retailers, known as quasi-integration. Finally, hierarchy governance focuses on control of the whole process.

As a result of the proposed typology, FT can be then characterised as governed by an external agent: the certification body. To better understand FT in practice it is important to describe the main requirements obtain certification.

\section{FLO- CERT}

In order to integrate the FT international criteria and to adopt a common system of certification, in 1997 Fairtrade Labelling Organizations International [FLO] was founded (FLO, 2009). The FLO is responsible for certifying producers and establishing the FT criterion. It follows international practices accepted by external monitoring and certifies products, giving them a guarantee label. It has social rules associated to technical specifications regarding the production of goods. Furthermore, there are also some environmental rules applied to each product. These rules aim to facilitate the acceptance of products on the international market. Under the FLO's list of certified food products (FLO, 2009) are tropical foodstuffs such as coffee, tea, cocoa, sugar, honey, fruit juices, fresh and dried fruit, bananas, vegetables, herbs and spices, rice, nuts, oils, wine, beer and rum. However, non-food products are also certified and commercialised such as cotton, flowers and sports balls. To produce or manufacture products carrying the FT banner, producers' associations must adhere to the set of standards enforced by the FLO concerning economic, social and environmental directives that follow certain internationally recognised criteria and conventions. 


\section{Criteria for Certification}

To produce or manufacture products carrying the FT banner, producers' associations must adhere to a set of standards enforced by FLO concerning economic, social, and environmental directives that follow certain criteria and conventions that have been internationally recognized. These rules should facilitate the acceptance of products internationally. To be eligible for FLO certification, producers' organizations must comply with both general criteria (applicable to any product) and product-specific criteria. For each criterion, there is a minimum requirement for achieving certification. In this sense, fair trading could be characterized as a buyer-driven chain, governed by an external agent, namely, the certification body. Governance is exercised through complex relationships amongst actors, where information is codified and the capabilities constantly verified.

In order to be eligible for the FLO certification, producers' organisations must comply with both general criterion (applicable to any product) as well as specific criterion (per product). Within each criterion there is a minimum requirement in order to the certification to be achieved. Two overarching directives organise the structuring of the criterion regarding the social, economic and environmental dimensions.

\section{Table 1: Criterions}

\begin{tabular}{|c|c|}
\hline \multicolumn{2}{|c|}{ Social Directives: } \\
\hline Criterion 1 & $\begin{array}{l}\text { Related to the development potential that a producer organization can have. As for the } \\
\text { minimum requirements, the producer organizations must be able to prove that FT will make a } \\
\text { difference to the business. The benefits generated will provide support for the growth of } \\
\text { business and will also enhance the livelihood of producers and their families. }\end{array}$ \\
\hline Criterion 2 & $\begin{array}{l}\text { It states that members of the organization must be small farmers; consequently, most of the } \\
\text { members of producer organizations must be characterized as small farmers. }\end{array}$ \\
\hline Criterion 3 & $\begin{array}{l}\text { Related to the organization, that it should be democratic, participatory and transparent. The } \\
\text { minimum requirements establish that members must control the structure of the organization. } \\
\text { The gathering of members at an annual general assembly should be the supreme forum for } \\
\text { decision making. During assemblies, a report of the activities and the annual accounts must be } \\
\text { approved by all members. }\end{array}$ \\
\hline Criterion 4 & Related to non-discrimination, meaning that no person can be denied participation. \\
\hline \multicolumn{2}{|c|}{ Economic Directive: } \\
\hline Criterion 5 & $\begin{array}{l}\text { About the FT price premium. The organization should be able to manage the FT premium to } \\
\text { the producers' benefit in a transparent way. }\end{array}$ \\
\hline Criterion 6 & $\begin{array}{l}\text { Related to export capacity; therefore, the organization needs to possess some physical assets } \\
\text { and be qualified to export. The minimum requirement to engage in exporting is a volume of } \\
20 \text { tons or the equivalent of one container load. The organization should have access to a } \\
\text { telephone line, the Internet and a computer system and evidence of good administrative skills. } \\
\text { The products traded must meet the current export quality standards, thus demonstrating that } \\
\text { the organization has the ability to export successfully directly or, if necessary, indirectly } \\
\text { through a partner. The contract established between seller and buyer must also provide a clear } \\
\text { indication that the transaction is FT certified. }\end{array}$ \\
\hline Criterion 7 & $\begin{array}{l}\text { Related to economic growth. One of FT's purposes is to increase the capacity of small } \\
\text { farmers to work in groups, aiming at the export market. Producers must develop their skills } \\
\text { and capacities so as not to depend on other people who could behave opportunistically. }\end{array}$ \\
\hline \multicolumn{2}{|c|}{ Environmental Directive: } \\
\hline Criterion 8 & $\begin{array}{l}\text { Related to the environment and the way resources are managed, such as water, natural forests } \\
\text { and other areas in the vicinity of the farm activity. The environment must be protected, } \\
\text { including control against erosion and waste management. Environmental monitoring } \\
\text { guidelines must be applied. }\end{array}$ \\
\hline
\end{tabular}

Therefore, this set of certification criteria implies the guarantee to consumers that by buying a FT certified product they will benefit the whole supply chain. Based on this set of criteria, a questionnaire 
was drawn up and used for collecting data as part of a research project on small honey producers in Brazil. Against this set of criteria the subsequent analysis was carried out.

Figure 1: Theoretical Framework

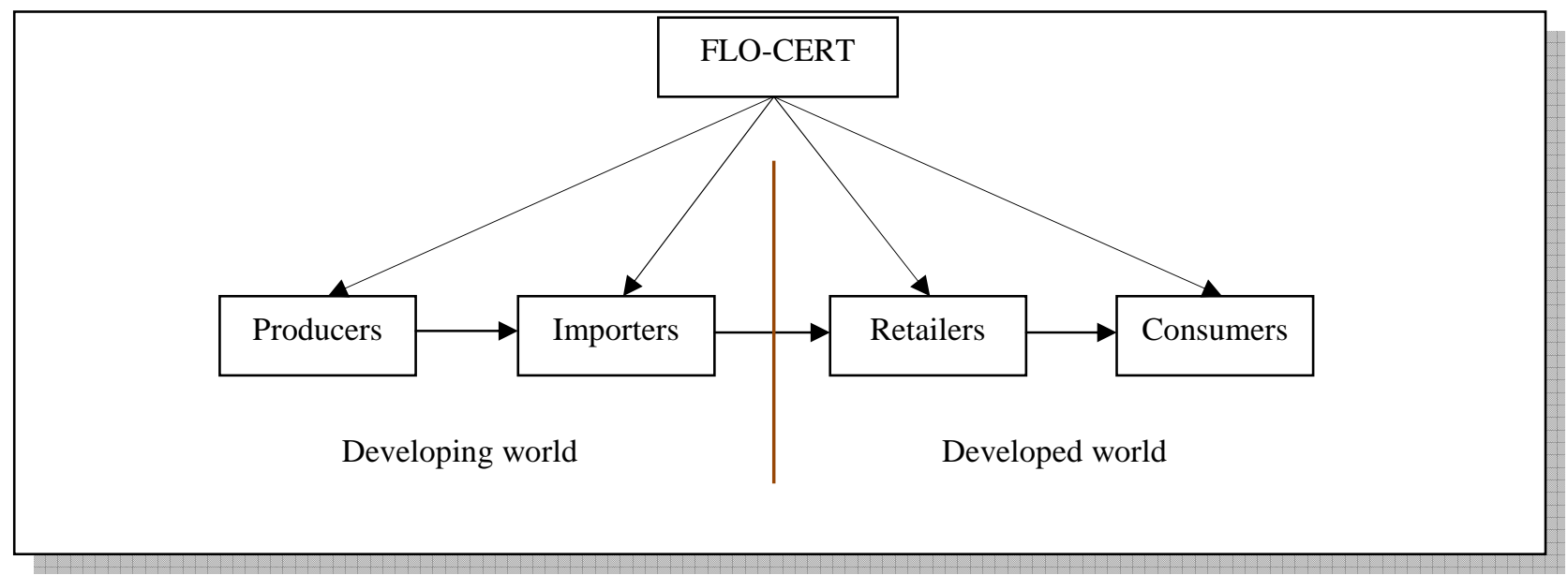

The framework results from the literature reviewed in the previous sections. It shows the division of production and consumption, as proposed by value chains. It also highlights the role of the certification body FLO-CERT setting the standards to get access to the FT market and also linking the distinguished agents of the global value chain.

\section{METHOD}

This research integrates different methodologies to study the honey chain and FT system. Paul (2005) identifies FT as a development project and suggests an integrated approach to evaluate its results when already established. Humphrey and Napier (2005) propose GVC as a tool to assess the impact of standards on supply chains in developing countries. They also use qualitative (maps, case studies) and quantitative techniques (measures, statistics). We used different qualitative methods in our research as detailed below:

$\mathbf{1}^{\text {st }}$ step - Secondary data collection - it aimed to improve the description of the honey chain structure and market data.

$\mathbf{2}^{\text {nd }}$ step - Participatory observation at meetings, seminars and events from the sector - This step involved the participatory observation in monthly meetings of a development project promoted by SEBRAE (federal institution responsible for the development of small and medium sizes business in Brazil). Participants at these meetings are the main leaders and representatives from institutions interested in honey production. The participatory observation is a research strategy that gives the researcher familiarity with the observed group and its practices. In this case, the researchers act not only as listeners, but mainly mapping the chain, which was one of the aims of the study.

$\mathbf{3}^{\text {rd }}$ step - In-depth interviews with experts - this was done in 2005, with interviews lasting around 3 hours with main leaders of honey production associations. The main goal was to obtain information to map the honey chain. We also interviewed two experts in Fair Trade certification, to go deeper in the knowledge about the aspects involved in the certification process. One of them works at FLO - CERT. The other interviewee is a specialist in Fair Trade who has worked as an inspector and liaison officer at FLO from Brazil and nowadays he is a Transfair consultant. These two interviews took place in Sao Paulo and lasted 4 hours, following a guideline with open questions to be able to have a better understanding of the FT system. 
$4^{\text {th }}$ step - Discussion of the honey chain map - this took place in 2006 with the participation of two technicians from the Brazilian Rural Assistance Institution as well as the leaders of the honey production association.

$5^{\text {th }}$ step - Presentation of the honey chain map - we organized two workshops to present the map to the experts. The fist meeting involved technicians and honey producers and was held in May 2006. The second workshop was held in June 2006 for an academic public interested in agribusiness and agri-food chains research at the University of Rio Grande do Sul. These workshops aimed to improve the chain design.

$6^{\text {th }}$ step - Transaction and Governance Analysis - in this step, we used the data collected in the previous steps to describe and analyse the transactions and governance involved in the different agents of the honey chain.

$7^{\text {th }}$ step - Selection of the region of the applied study- after analysing all the data gathered, we defined the region of Osorio to be the location to carry out the fieldwork. This region was chosen due to a number of economic, social and environmental features which represent a good potential to frame the criteria to FT projects.

$8^{\text {th }}$ step - Fieldwork - We conducted an appraisal about the existing bee-keeper associations in the 22 cities from the region of Osorio.

$9^{\text {th }}$ step - Case studies through semi-structured interviews with bee-keepers from associations and direct observation. We used a questionnaire based on the FLO criteria for semi-structured interviews with the presidents of six associations found in the studied region and four interviews with the affiliated producers to these associations to validate some information. These interviews lasted around 2 hours each. The questionnaires had 81 questions divided into six groups: descriptive data, production features, financial issues, social issues, commercialization and distribution. Each group of questions aimed to analyse each association according to the FLO criteria. In the first group, a general description of the association was given, verifying whether this association was qualified to export, in to addition, details such as organizational structure and members' participation in decision making, among others. In the second group, production features, questions were asked regarding the number of beehives and total honey produced per year. In this same group, questions focusing on organic certification, quality control and lab tests were asked. In the infrastructure group of questions, an assessment was made of the facilities for honey processing, which has a number of technical specificities and is needed to obtain export qualification. The next group of questions aimed to focus on financial issues such as loans, debts, resources to invest in FT certification, among others. The last group of questions focused on social issues and sought to describe how the honey producers lived, their annual income, if they performed other economic activities and the share of this activity in the family income, the role of women and work

$\mathbf{1 0}^{\text {th }}$ step - Data organisation and analysis - analysis of all the previous steps of the research, making possible the identification of those associations that could meet the criteria for Fair Trade certification.

The main results of these multiple methods are summarised in the next section.

\section{SMALl HONEy Producers IN BRAZIL}

This section presents the honey chain and the case studies.

The fieldwork research was carried out in the region of Osório between November and December, 2006. The region of study is located in the east of the Rio Grande do Sul State, $100 \mathrm{~km}$ from the state's capital, Porto Alegre and its metropolitan district. In total, there are twenty-two towns in the region, most of them along the northern Atlantic coast of the state. Six honey associations were 
researched, including a total of 128 bee-keepers, who produce around 390 tonnes of honey per year. Other honey producers not organised into associations also work in this region, but as they do not fulfil the association membership requirement, they were not included in the scope of this study.

Figure 2: Honey Chain Scheme

SCHEME OF HONEY CHAIN IN RIO GRANDE DO SUL

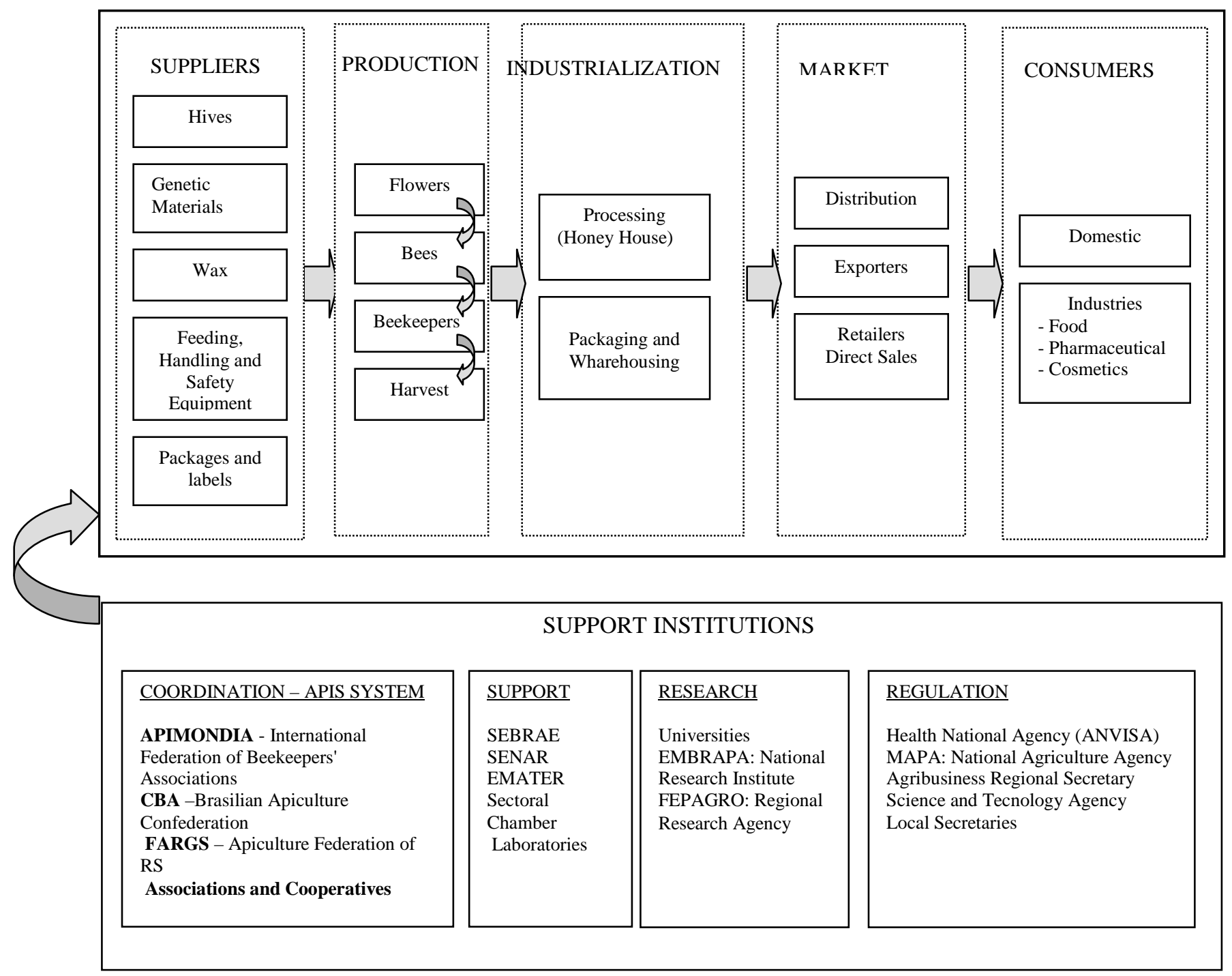

From Figure 2 it is possible to identify the main segments that integrate the chain, dedicated to honey production, which are:

- Inputs relating to the production of honey, such as the acquisition of the boxes to house the hives, wax matrix so that the bees can start producing honey, safety equipments (overalls, gloves, masks, boots, fumigator), bee swarms, queens and the area where the beehives are located.

- Production relates to the production carried out by the bee-keeper from the apiary installation to the handling of the hives and the harvesting of honeycombs and their transport to the Honey House.

- Agri-industrialization refers to activities in the Honey House such as centrifugation, filtering, decantation for 48 hours, stocking, classifying, packaging and labelling. 
. Commercialisation relates to when the honey is commercialised and it consists of two basic forms. One is when the sale is done by the bee-keeper himself in farmers' markets or by distributing to grocery stores, stands, bakeries and other small retailers. The other is in bulk quantity, where the honey is usually packaged in containers of 50,100, 200 and 300 litters for export. This type of sale is normally conducted through larger companies, which have sales warehouses, or specialized companies that can offer the product on a large scale.

In order to ascertain whether the six associations would attend the criteria to obtain the FLO certification, the authors used semi-structured interviews. The FLO criterion was instrumental in guiding the questions to be asked. Direct observation was also carried out to verify the veracity of some responses.

Table 2 shows a summary of the assessment, with the six associations according to FLO criteria.

Table 2: FT Criteria Services from Six Studied Associations in Osorio

\begin{tabular}{|c|c|c|c|c|c|c|c|}
\hline \multicolumn{8}{|c|}{$\begin{array}{l}\text { SYNTHESIS OF ASSOCIATIONS } \\
\end{array}$} \\
\hline \multirow{2}{*}{\multicolumn{2}{|c|}{ FLO Criteria }} & \multicolumn{6}{|c|}{ Associations } \\
\hline & & AAPO & AAO & APITRA & APIMAQ & APA & AAFTV \\
\hline \multirow{4}{*}{\begin{tabular}{l}
$\circlearrowright$ \\
$\circlearrowright$ \\
$\circlearrowright$ \\
\hdashline
\end{tabular}} & 1) Potential Development & No & No & No & Partial & Yes & Yes \\
\hline & 2) Small holders & Partial & No & Yes & Yes & Yes & Yes \\
\hline & $\begin{array}{l}\text { 3) Democracy, Participation and } \\
\text { Transparency }\end{array}$ & Yes & Partial & No & Partial & Yes & Yes \\
\hline & 4) Non discrimination & Yes & Yes & Yes & Yes & Yes & Yes \\
\hline \multirow{3}{*}{ 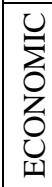 } & 5) FT Premium Price & Yes & Partial & No & Partial & Yes & Yes \\
\hline & 6) Export Capacity & Partial & Yes & No & Partial & No & No \\
\hline & 7) Economic Growth & Yes & No & No & Yes & Yes & Yes \\
\hline \multicolumn{2}{|r|}{ 8) Environmental Protection } & Partial & Partial & Partial & Partial & Partial & Partial \\
\hline \multicolumn{2}{|r|}{ Aptitude to obtain FT certification } & No & No & No & Partial & Partial & Partial \\
\hline
\end{tabular}

Our findings show that the most difficult criterion to meet regarding these honey associations has to do with export capacity. This is partially because these honey producers have not even been certified by the Brazilian Ministry of Agriculture to trade either inter-state or to export. This was one of the main problems faced by the bee-keepers who were interviewed. In terms of structure, there is a lack of resources to build honey processing installations as well as to purchase the necessary equipment. Some bee-keepers also take part in other economic activities to generate enough savings to revert to the business, since access to credit to invest in infra-structure is made difficult.

Criterion 8 refers to the preservation of the environment, which is only partially met by all six associations. Despite these associations not using agrochemicals, there is no formal control regarding environmental practices, such as an Internal Control System [ICS]. Regarding the discrimination criterion, this was not observed. Therefore, there was no overt perception of any prejudice, be it racial, religious or of gender. This criterion, although not considered a problem in the region studied, is important when operating in fair-trading networks to ascertain that no such issues could be raised when it came to the honey being accepted on the international market. FLO, by acting globally, is concerned about discrimination issues in many countries. For the criterion of economic development, we tried to verify the partners`socio-economic condition, as well as the association's infra-structure and its level of commitment towards the certification and the activity. We could see that apiculture is an activity used to complement the family's income and sometimes beekeeping a hobby. Hence, 
criteria 3 and 5 relating to the decision-making process within the associations indicate that both genders were well represented through an electoral ballot. Exceptions to such a good practice could be attributed to a couple of associations that had just been set up.

Overall, if the criteria as defined by FLO to qualify associations for FT certification were followed, three of the studied associations could obtain FT certification provided some adjustments were made. In the case of deciding to obtain the FT certification, these associations would have a product with high specificity which end consumers could perceive as dedicated assets, not only related to the social attributes involved in the production, but also to product quality attributes. As a result of being subject to adhering to FT certification criteria, certified honey implies a system with a specific governance structure, with this certification being the main driver of governance. Being certified would require a change in the way transactions take place throughout the chain. For example, as shown in Figure 3, regarding the transactions between bee-keepers and importers, the latter buy honey from a producer, and they are responsible for the payment of the minimum price and premium. They can also give assistance to producers: (a) by advising them and supporting them technically in product development; (b) making training available; (c) supporting them in social and economic difficulties; and (d) financing the early stages of production or the harvest. The complexity of the standards and, in consequence, the need to monitor and assure compliance requires tight governance. This governance would be exercised by FLO instead of an internal agent as proposed by the GVC. Transactions between the retailer and the final consumer use certification as an instrument which guarantees the consumer that a certain product has the desired social, environmental and quality attributes. The assets have high specificity and FLO is in charge of organising and transferring technical and marketing knowledge from the consumer market to producers located in developing countries.

Figure 3: Changes in the Transactions after the Compliance with the FT Criterion

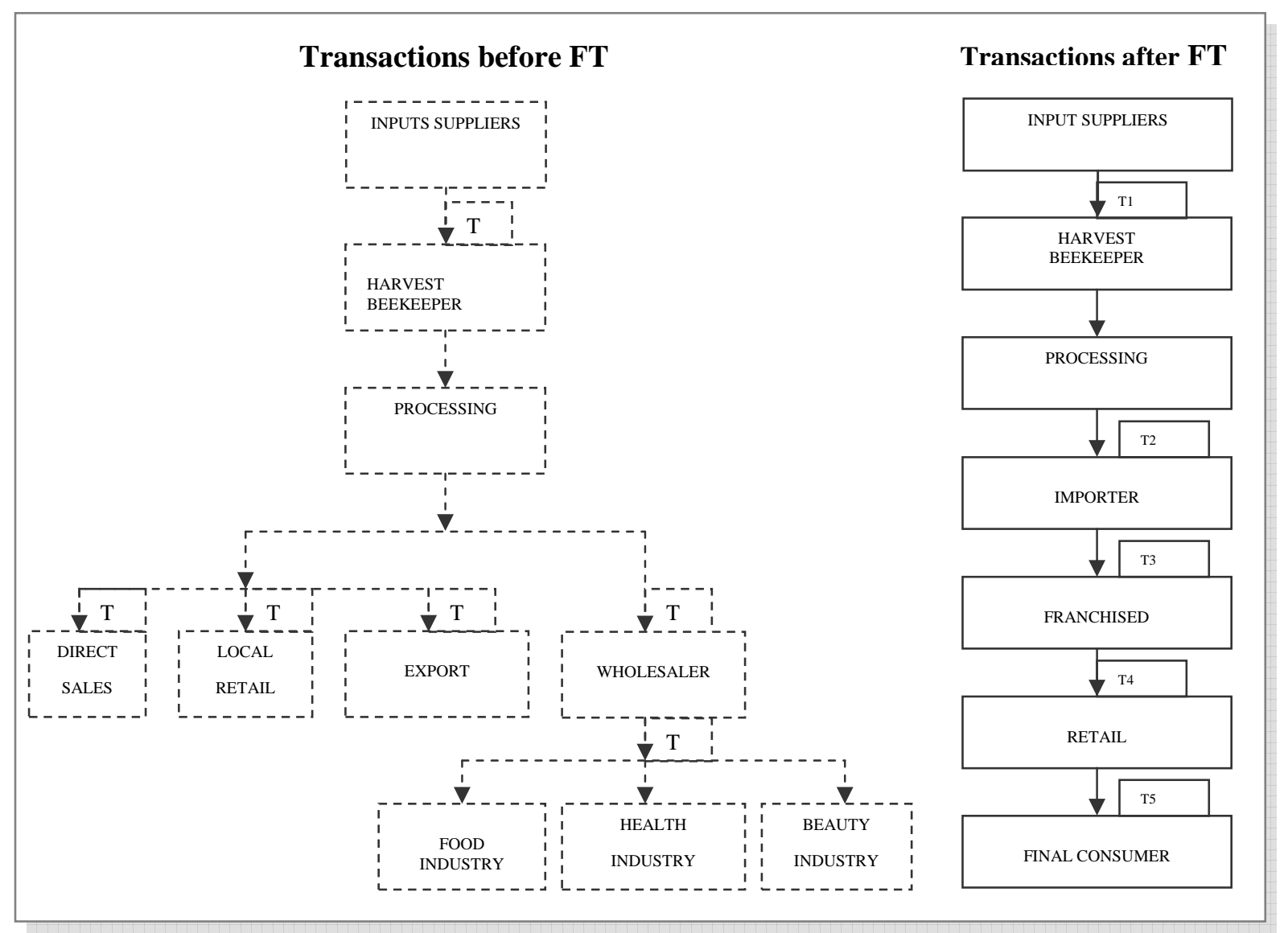


However, it could be argued that perhaps small honey producers in Brazil need not go to these lengths to obtain fair-trade certification provided they produce top quality products. So far, ethical demand for fair-trading products has sustained a growing market.

\section{FINAL REMARKS}

As mentioned above, the internationalisation or, perhaps more accurately, the globalisation of fairtrade supply chains is a recent fact that still requires more studies with regard to the implications it might have for producers, intermediaries and consumers. It would not be wrong to infer that FT appeared as a message for inclusion (Low \& Davenport, 2006) but there are barriers for small producers, such as the honey associations studied, to overcome.

This study brings theoretical and managerial implications. The latter, as the study proposes, at the end of such a process, means that the fair-trade system as a whole reinforces what the Global Value Chain analysis typifies as the buyer-driven chain or, at least, a tighter relationship such as the captive one (Gereffi, Humphrey, \& Sturgeon, 2005). Fair-trade marketing is moving towards becoming dominated by large food retail formats carrying branded fair-trade merchandise, which is considered by Low and Davenport (2006) as an assimilation process. In parallel, Audebrand and Iacobus (2008) highlight the role for marketers involved in FT activities not to reduce FT to a mere commodity. FLO, as the chain governor, is more involved in monitoring compliance to the standards, brand building and product positioning (similar to the athlete shoes and apparel examples provide by Gereffi, 1999).

As for managerial and public policy implications, in the associations studied, we could not identify any capacity for the honey associations to play this role without assistance. This exploratory research identified some difficulties in the honey associations under study to meet criteria such as export capacity and organization capacity. Honey producers need to obtain a license from the Ministry of Agriculture to be able to export. For the small associations studied, the Ministry requires some facilities known as Honey House with a number of high costs technical specifications. This is considered as a barrier to access to more sophisticated markets, restricting their production and leaving these small producers to clandestine markets. The other criterion, organizational capacity, is also difficult to comply with since many producers also perform other agricultural activities. This does not motivate the producers to develop the association in terms of both quality and quantity.

These two items seem to be the main obstacles to bee-keepers being included in the FT system and are related to the capability of suppliers as proposed by Gereffi et al. (2005). The codification of information and complexity of transactions is transferred by FLO, which intermediates the relationship between the buyer and the seller. For public policies, there is an important way for institutions such as SEBRAE, APEX, and Ministry of Agrarian Development, to help and train these small producers to overcome these limitations to access export markets. On the other hand, this study identifies that managers interested in investing in FT certification should be aware that there is a risk of becoming overspecialised in a brand which is still not recognized by Brazilian consumers.

We highlight that this study reinforces the recent changes in the relationships between buyers and producers connected to international trade. The agri-food globalisation chain shows the division of productive activities in different places. Recently, the FT commerce has been developing and providing market access to agricultural products from small producers located in different developing countries. It also has the possibility of going mainstream, using the existing much wider distribution channels of large retailers. Since 2007, there has also been a trend in mergers and acquisitions in which large players are becoming involved with the fast-growing ethical market, for example L'Oreal acquired Body Shop and Cadbury's Schweppes bought Green \& Black's.

The adoption of FT certification allows small producers to gain access to international market and to add value to their products. Nevertheless this study points out that certification has its entry barriers 
represented by the formalization of associations between producers, export capacity and the costs of certification, among others. However, as pointed out by Raynolds et al. (2007), non-economic factors also influence the shape of the FT system and future research should also investigate the role of social networks, public policies in developing countries and other aspects.

\section{REFERENCES}

Aguiar, L. (2006) Are ethically coffees sustainable? Farmers Club, 8(5), 12-15.

Audebrand, L. K., \& Iacobus, A. (2008). Avoiding potential traps in fair trade: a social representation perspective. Journal of Strategic Marketing, 16(1), 3-19.

Dolan, C. S., \& Humphrey, J. (2000). Governance and trade in fresh vegetables: the impact of UK supermarkets on the African horticulture industry. Journal of Development Studies, 37(2), 147-176.

Fairtrade Labelling Organizations International. (2009). Fairtrade standards for honey for smallfarmers' organisations [Superseded previous versions: 01.12.2005]. Retrieved July 28, 2009, from http://www.fairtrade.net/fileadmin/user_upload/content/02-09_Honey_SPO_EN.pdf

Gereffi, G. (1994). Organization of buyer-driven global commodity chains: how U.S retailers shape overseas production networks. In G. Gereffi \& M. Korzeniewicz (Eds.). Commodity chains and global capitalism (pp. 95-122). Westport, CT: Praeger Publishers.

Gereffi, G. (1999). International trade and industrial upgrading in the apparel commodity chain. Journal of International Economics, 48(1), 37-70.

Gereffi, G., Humphrey, J., \& Sturgeon, T. (2005). The governance of global value chains. Review of International Political Economy, 12(1), 1-27.

Harrison, R., Newholm, T., \& Shaw, D. (2005). The ethical consumer. Newbury Park, CA: Sage.

Humphrey, J., \& Napier, L. (2005). FAO AGA/ESC initiative on market exclusion. The value chain approach as a tool for assessing distributional impact of standards on livestock markets: guidelines for planning a programme and design case studies (Research Report), Brighton, UK, Institute of Development Studies, the University of Sussex.

Jones, P., Comfort, D., \& Hillier, D. (2004). Developing customer relationships through fair rade: a case study from the Retail Market in the UK. Management Research News, 27(3), 77-87.

Kaplinsky, R. (2000). Spreading the gains from globalisation: what can be learned from value chain analysis [Working Paper $\mathrm{N}^{\circ}$ 110]. Institute of Development Studies, the University of Sussex, Brighton, United Kingdom.

Lewin, B., Giovannucci, D., \& Varangis, P. (2004). Coffee markets: new paradigms in global supply and demand [Discussion Paper N ${ }^{\circ}$ 3]. World Bank - Agriculture and Rural Development, Washington, DC. Retrieved August 13, 2004, from http://lnweb18.worldbank.org/ESSD/ardext.nsf/11ByDocName/ExecutiveSummary-CoffeeMarkets

Low, W., \& Davenport, E. (2006). Mainstreaming fair trade: adoption, assimilation, appropriation. Journal of Strategic Marketing, 14(4), 315-327.

Paul, E. (2005). Evaluating fair trade as a development project: methodological considerations. Development in Practice, 15(2), 134-150.

Porter, M. (1985). Competitive advantage. New York: Free Press. 
Raynolds, L., Murray, D., \& Wilkinson, J. (2007). Fair trade in the agriculture and food sector: analytical dimensions. London: Routledge.

Vieira, L. M., \& Traill, W. B. (2008). Trust and governance of global Chains: the case of a Brazilian beef processor. British Food Journal, 110(4), 460-473. 